\title{
Effectiveness of Micronizing Zinc Borate to Improve Its Fungicidal Properties
}

\author{
Claudia M. Ibáñez, ${ }^{\mathrm{a}, *}$ Alvaro Camargo, ${ }^{\mathrm{a}}$ Carlos Mantero, ${ }^{\mathrm{b}}$ Ricardo Faccio, ${ }^{\mathrm{c}}$ \\ Antonio Malanga, ${ }^{\mathrm{d}}$ and Mario Rabinovich ${ }^{\mathrm{a}}$
}

\begin{abstract}
The effectiveness was evaluated for an established wood preservative, zinc borate, prepared in an agitating bead mill to extensively reduce its particle size. The generated micro- or nano-particles of zinc borate were characterized by X-ray powder diffraction, and the particle size distribution was determined to evaluate the effect of milling. Then the fungicidal effectiveness of the zinc borate of both milled and unmilled samples were assayed against brown- and white-rot fungi, on culture medium and on conifer and hardwood as substrates. Treated wood samples were subjected to leaching tests. Scanning electron microscopic images of wood samples were examined to analyze the distribution of zinc borate within the wood. The micronized zinc product kept its crystal structure intact, and it increased the proportion of particles with diameters below $100 \mathrm{~nm}$ by $25 \%$ when compared to the unmilled product. Malt extract-agar medium supplemented with $2.5 \%$ of w/w milled and unmilled zinc borate inhibited fungal growth tested. Both milled and unmilled zinc borate protected the wood when not subjected to leaching. The milled sample of zinc borate improved resistance to leaching, which would allow its application in environments of high moisture content; however, it did not improve the fungicidal action against decay fungi.
\end{abstract}

Keywords: Zinc borate; White-rot; Brown-rot; Preservative; Fungicide; Leaching; SEM

Contact information: a: Instituto Superior de Estudios Forestales, Sede Tacuarembó, Universidad de la República, Tacuarembó, Tacuarembó, Uruguay CP 45000; b: Departamento Forestal, Facultad de Agronomía, Universidad de la República, Montevideo, Uruguay; c: Centro NanoMat \& Cryssmat-Lab, DETEMA, Facultad de Química, Universidad de la República, Montevideo, Uruguay; d: Instituto Polo Tecnológico de Pando, Facultad de Química, Universidad de la República, Montevideo, Uruguay;

*Corresponding author: marcela.ibanez@cut.edu.uy

\section{INTRODUCTION}

The composition and physicochemical properties of wood make it susceptible to deterioration by microorganisms and abiotic agents. For more than a century, fungicidal and pesticide-based treatments have been used for preventing wood decay.

Among waterborne preservatives, inorganic compounds have shown long-term effectiveness against a broad spectrum of species (Eaton and Hale 1993); zinc, boron, and zinc borate have been widely used (Stirling and Temiz 2014). In particular, zinc borate has been used as an additive for lacquers, paints, polymeric materials, and in flame retardant formulations for wood impregnation. The zinc borate has also been used to improve the properties of wood composites and particleboard against wood-rotting fungi and as a fire retardant (Tascioglu et al. 2013, 2014, 2017). 
Within the past decade, numerous products for wood impregnation have been developed, including micronized particles and/or nanoparticles (Freeman and McIntyre 2008; Kartal et al. 2009; Clausen et al. 2009, 2010; Akhtari and Nicholas 2013; Civardi et al. 2015a). Micronized particles are produced by mechanical milling of insoluble metal compounds (copper, zinc, silver etc.) to a particle size below $1000 \mathrm{~nm}$ in at least $90 \%$ of the bulk material, using dispersing and wetting agents in aqueous or oily media. The particle size of nanometric products is below $100 \mathrm{~nm}$ in at least one dimension, and their behavior differs markedly from that of their constituent metal elements (European Commission 2011).

The enhanced biocidal effectiveness and leaching resistance of nanoparticles stems from their ability to be transported through the wood ultrastructure, where pore size can be well below $1000 \mathrm{~nm}$. For example, the membrane openings of bordered pits are usually between $400 \mathrm{~nm}$ and $600 \mathrm{~nm}$ and provide the potential for high metal retention in the wood, therefore resulting in higher durability of wood (Freeman and McIntyre 2008; Kartal et al. 2009). Nanometric metals also increase the effective superficial area of the metal in an evenly dispersed layer (Freeman and McIntyre 2008). This nanoparticle film on the wood surface can provide resistance to leaching (Clausen et al. 2011). The biocidal profile of nanoparticles against xylophages differs from that induced by the same metals in ionic form. In addition, nano-particulate metals do not induce lignocellulosic enzyme activity (Shah et al. 2010).

Zinc- and boron-based nanomaterials dominate the topics of current research in this area. Nano-zinc has been reported to be more resistant to leaching than soluble metal oxides (Kartal et al. 2009). Nano-zinc oxide is effective against termites (Clausen et al. 2011; Lykidis et al. 2016 a, b) and it improves heat transfer within the wood matrix, allowing temperatures to reach $185{ }^{\circ} \mathrm{C}$ during heat treatment, thereby increasing resistance to biological attack (Ghorbani-Kookandeh et al. 2014). The nano-zinc borate has been shown to be effective against pine decay fungi, brown rot fungi, and termites (Lykidis et al 2013, 2016a, 2018).

The effect of micronized copper is well known (Freeman and McIntyre 2008; Civardi et al. 2015b); when applied to the wood, one part reacts with its components and the other remains in the form of copper particles that give a reservoir effect (Xue et al. 2014). No studies have reported on the use of micrometric zinc, boron, or zinc borate for wood preservation.

Nevertheless, most of the studies available in the literature were carried out using pure, analytical grade materials with known and sometimes uniform particle size distributions. Thus far, few studies have addressed the preservative potential of materials containing both micro- and nano-sized particles.

Therefore, the objective of this study was to obtain a readily available micronized zinc borate to be used as wood preservative. After milling the product as to improve its penetration in wood, and the characteristics of the milled product as wood preservative were compared to those of the unmilled one. It was hypothesized that an increase in the content of nanometric fraction of particles in the preservative would increase the effectiveness against decay fungi and leaching resistance. Both milled and unmilled products were assayed for their ability to protect Pinus taeda L., Eucalyptus grandis Hill ex Maiden and Populus sp. L. wood against white and brown rot fungi. The leaching resistance of the impregnated products was also tested. 


\section{EXPERIMENTAL}

\section{Preparation and Characterization of Milled Zinc Borate}

Zinc borate, produced from commodities in a low-cost process, without using pressure or high temperature, was purchased from Perrín S. A. (Montevideo, Uruguay). A $34 \%(\mathrm{w} / \mathrm{w})$ zinc borate suspension in water was prepared, to which traces of dispersant, moistener, surfactant, and defoamer were added (0.01\%; w/w) (Hydropalat 3204, 1080, from BASF Corp., Ludwigshafen, Germany; Bentone LT, Elementis Specialties, London). The mixture was then fed to a continuously agitating bead mill designed by Pinturas Inca, S. A. (Montevideo, Uruguay). The agitating period was of nine hours. Zirconium beads 1.2 $\mathrm{mm}$ in diameter were used as the milling medium.

X-ray powder diffraction (XRPD) data was collected for the milled and unmilled zinc borate on a Rigaku Ultima IV (285 mm radius; Tokyo, Japan) powder diffractometer operating in Bragg-Brentano geometry. Monochromatized $\mathrm{CuK} \alpha$ radiation $(\lambda=1.5418 \AA)$ with a diffracted beam from a bent germanium crystal was used to collect data over the $2 \theta$ range of $10^{\circ}$ to $60^{\circ}$ at a scanning rate (step size) of $0.02^{\circ}$, using a scintillation detector.

A Coulter LS 230 (Beckman Coulter, Inc., Brea, CA, USA) particle size analyzer was used to compare the particle size distribution of the milled and unmilled zinc borate samples, using water as fluid, at a run length of $90 \mathrm{~s}$ and an obscuration of $11 \%$. Particle morphology was assessed by scanning electron microscopy (SEM) with a JEOL JCM6000: Neoscope II Benchtop (JEOL USA Inc., Peabody, MA, USA), used in high vacuum mode with an accelerating voltage of $10 \mathrm{kV}$ and SE detector.

The particle size distribution was determined for each sample by a laser diffraction pattern and mathematical particle volume calculation, considering the particles as nonporous spheres and using XRPD data as diameter measurements.

\section{Fungus Growth on Zinc Borate-Supplemented Culture Medium}

Three species of white rot fungi [Phanerochaete chrysosporium (1556, DZM), Punctularia atropurpurascens (H2126 CCMFQ), and Trametes versicolor (H2140 CCMFQ)] and one species of brown rot fungi [Gloeophyllum trabeum (H2130 CCMFQ)] were obtained from the fungal collection of Cátedra de Microbiología, Facultad de Química, Universidad de la República, Uruguay.

The strains were maintained on a medium containing malt extract $(12.5 \mathrm{~g} / \mathrm{L})$ and agar (20 g/L) (MA, malt extract-agar medium), sterilized by autoclaving at $121^{\circ} \mathrm{C}$ for 15 min. Malt extract and agar were purchased from Oxoid Ltd. (Basingstoke, UK).

Plastic Petri dishes (85 mm inner diameter) containing MA, with and without zinc borate, were inoculated with a mycelial plug ( $5 \mathrm{~mm}$ diameter) obtained from actively growing mycelia. Dishes were incubated at $28{ }^{\circ} \mathrm{C}$ for 21 days.

The MA was supplemented with milled and unmilled zinc borate, respectively, to final concentrations of 2.50, 1.25, 1.00, 0.65, and $0.01 \%(\mathrm{w} / \mathrm{w})$ in each case. The solid was added while the medium was still liquid. The minimum growth inhibitory concentration (MIC) was defined as the lowest concentration at which growth inhibition was total (Borokhov and Rothenburger 2000). Mycelial growth was assessed according to the size (diameter measured in $\mathrm{mm}$ ) of fungal colonies grown in micronized zinc boratesupplemented MA (Hatvani and Mécs 2003). Unsupplemented MA was used as the control medium. 
For each species, three replicate samples were collected for each concentration of zinc borate in the culture medium (including three control samples). Initial growth rates $(\mathrm{mm} / \mathrm{d})$ were calculated according to incubation data from days 1 to 10 .

\section{Specimens Preparation}

Blocks of Eucalyptus grandis, Populus sp., and Pinus taeda mature sapwood (50 $\mathrm{mm}[\mathrm{L}] \times 25 \mathrm{~mm}[\mathrm{~T}] \times 15 \mathrm{~mm}$ [R], grain direction parallel to the $50 \mathrm{~mm}$ edge) free of defects and with no visible evidence of fungal infection were prepared according to EN 113 (1996). The blocks were oven-dried at $103 \pm 2{ }^{\circ} \mathrm{C}$ for $48 \mathrm{~h}$ and weighed (to nearest $0.001 \mathrm{~g}$ ) for initial dry weight determinations. Test samples were selected so that their density did not differ from the mean oven-dried density value by over $15 \%: 0.44 \mathrm{~g} / \mathrm{cm}^{3}$ for P. taeda, $0.49 \mathrm{~g} / \mathrm{cm}^{3}$ for E. grandis, and $0.41 \mathrm{~g} / \mathrm{cm}^{3}$ for Populus sp.

All blocks were maintained at $20{ }^{\circ} \mathrm{C}$ and $65 \%$ relative humidity (RH) until equilibrium was reached at a moisture content of approximately $12 \%$. Untreated blocks used as controls were not treated further.

\section{Wood Protecting Action and Leaching of Milled and Unmilled Zinc Borate Impregnated in Wood Substrates}

Impregnation of wood blocks (30 of each wood species) was carried out using a zinc borate water suspension at two concentrations: $2.5 \%$ and $5.0 \%$ total solids, for both milled and unmilled products. The impregnation method was vacuum-to-vacuum. Samples were maintained in desiccators under vacuum ( $4 \mathrm{kPa}$ ) for $30 \mathrm{~min}$ prior to allowing zinc borate suspension into the desiccators. Samples remained submerged for an additional one hour. Zinc borate retained in samples after impregnation was then determined through the mass increase of each block (when compared to initial dry mass) per unit of wood volume. Treated and control samples were stored at $60 \pm 2{ }^{\circ} \mathrm{C}$ for $36 \mathrm{~h}$ to provide same environment and to allow fixation.

Half of the impregnated samples (15 blocks of each wood species) were subjected to leaching tests according to EN 84 (1997), which is an accelerated ageing test for samples treated with a preservative simulating long-term use condition. After the samples were maintained under vacuum (4 kPa) for $20 \mathrm{~min}$, five times their volume of deionized water was allowed into the desiccator, until atmospheric pressure was reached. Then the samples were soaked for $2 \mathrm{~h}$ and finally maintained in fresh deionized water, changed daily, for 14 days.

Samples were tested for resistance to fungal decay according to standard method EN 113 (1996). T. versicolor and G. trabeum were inoculated onto solid MA medium in $600 \mathrm{~mL}$ flasks. When mycelial growth covered the flask bottom (c. 3 weeks culture), one control and two treated samples (previously sterilized at $121{ }^{\circ} \mathrm{C}$ for $15 \mathrm{~min}$ ) were placed in each flask. The flasks were subsequently incubated in the dark at $23 \pm 2{ }^{\circ} \mathrm{C}$ and $60 \%$ to $70 \% \mathrm{RH}$. Ten samples treated of each concentration were cultured as control without fungus.

After 16 weeks, the samples were oven-dried at $102 \pm 2{ }^{\circ} \mathrm{C}$ and weighed for final dry weight determination. Fungicidal effectiveness was assessed in terms of dry mass weight loss percentage using Eq. 1,

$$
\mathrm{WL}(\%)=\left(w_{1}-w_{4}\right) * 100 / w_{1}
$$

where $w_{1}$ is initial dry weight of the samples, and $w_{4}$ is the final dry weight of the samples after culture. 
The distribution of impregnated zinc borate inside wood structure, was assessed using SEM images of treated and control wood samples. The SEM analysis was used in high vacuum mode at accelerating voltage of $10 \mathrm{kV}$ and SE detector.

\section{Analysis of Boron and Zinc Acid digestion}

Five blocks of each wood species from each treatment were milled together in a horizontal blade mill (Marconi Modelo MA 680, San Pablo, Brazil) and sieved through a 30-mesh screen before being digested (Kurz et al. 1973; Hu and Qi 2014). The amounts of zinc and boron in the samples were determined by flame atomic absorption spectrometry and electrochemical techniques, respectively (Anzano and González 2000).

The digestion procedure was based on a modified method of AWPA A7-12 (2014). As microwave was not used for digestion, a previous assay was made in which wood samples were digested in different acidic mixtures $\left(\mathrm{HNO}_{3}-\mathrm{HCl}, \mathrm{HNO}_{3}-\mathrm{HCl}, \mathrm{HNO}_{3}-\mathrm{HCl}-\right.$ $\mathrm{H}_{2} \mathrm{O}_{2}$ ), selecting the one that allowed the highest zinc recovery.

About $0.5 \mathrm{mg}$ of the milled wood sample was weighed and transferred to a flask and then heated in a stirring water bath, adding $\mathrm{HNO}_{3}(65 \%$, w/w) for Eucalyptus, and $\mathrm{HNO}_{3}(65 \%$, w/w) and $\mathrm{HCl}(35 \%$, w/w), 50:50 for Pinus until the temperature reached 80 ${ }^{\circ} \mathrm{C}$, and then left for 120 min (Ramanathan and Ting 2015). It was later allowed to cool, filtered through a $0.45 \mathrm{~mm}$ filter, and made up to a volume of $100 \mathrm{~mL}$ with distilled water (Wilson 1958; Dawson et al. 1990).

\section{Quantification of boron and zinc elements}

The zinc (Zn) concentration was determined by using an atomic absorption spectrometer equipped with a 900T PinAAcle flame oven (Perkin Elmer, Kentucky, USA) (Anzano and González 2000), while the boron (B) concentration was determined by a potentiometric method, in which a complex between boric acid (or borates present in the sample) and mannitol (Dawson et al. 1990) was formed. This complex acidified the solution and was titrated using $\mathrm{NaOH}(0.025 \mathrm{M})$ solution. The valoration was made with a glass electrode and a Thermo Scientific Orion Stara 3215 (USA) potentiometer. The amount of $\mathrm{B}$ was equivalent to the amount of $\mathrm{NaOH}$ required to reach the initial $\mathrm{pH}$ of the sample (Wilson 1958).

\section{Statistical Analysis}

Results were analyzed by STATISTICA software (version 7.1 2005, Statsoft Inc., Tulsa, OK, USA). Duncan's test was used to assess the significant differences among treatments, with 95\% confidence level.

\section{RESULTS AND DISCUSSION}

\section{Characterization of Milled Zinc Borate}

As homogeneous particle size distribution and the ability to penetrate the ultrastructure of wood are essential for the preservative effectiveness (Eaton and Hale 1993), prior to testing for fungicide effectiveness, the milled and unmilled zinc borate samples were analyzed in order to verify the effect of milling on the preservative effectiveness. 
The XRPD analysis (Fig. 1) showed that both milled and unmilled zinc borate presented a $\mathrm{Zn}_{4} \mathrm{O}\left(\mathrm{BO}_{3}\right)_{2}$ crystal structure. This crystal phase is described as a rhombohedral crystal system with space group R-3c, with $\mathrm{a}=9.9115 \AA$ and $\mathrm{c}=48.602 \AA$ according to Harrison et al. (1993).

There was no significant difference in either peak position or intensity between the milled and unmilled zinc borate samples. Analysis of full width at half maximum (FWHM) shows that the size of the crystalline domain is around $100 \mathrm{~nm}$.

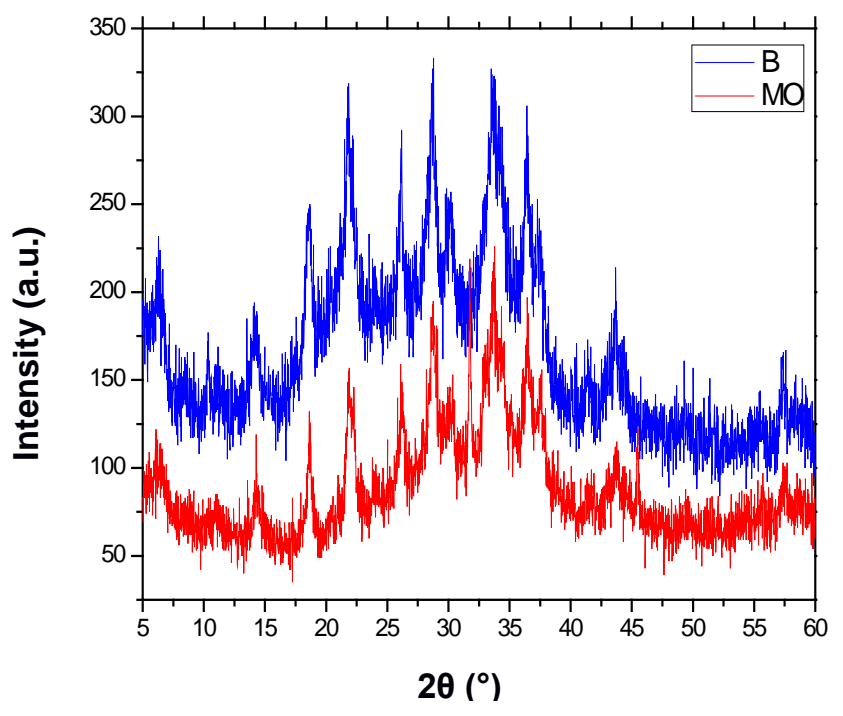

a)

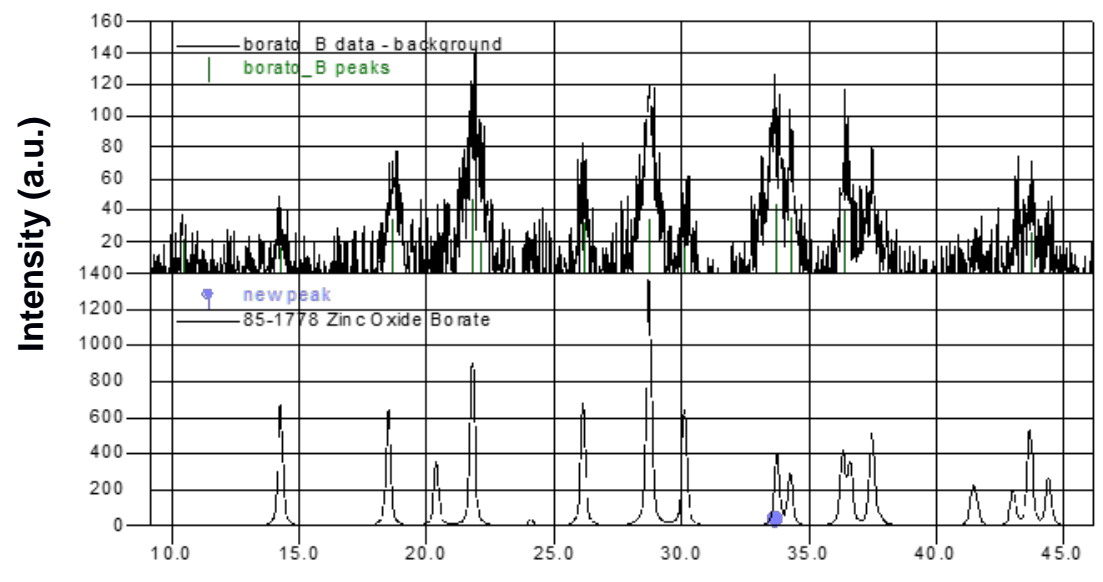

b)

$2 \theta\left({ }^{\circ}\right)$

Fig. 1. a) X-ray powder diffraction analysis of milled and unmilled zinc borate; and b) peak details.

Milling effectiveness was assessed according to the particle size distribution of the milled zinc borate, which in turn reflects the percentage of particles that can penetrate and be transported throughout the wood matrix. Figure 2 shows the particle volume distribution of the suspension. Milling was found to increase by less than 25\% the proportion of smallest-sized particles with diameters below $100 \mathrm{~nm}$. This demonstrated that the nanometric content varied very little between the milled and unmilled products. However, 
the milling decreased the fraction of particles larger than $250 \mathrm{~nm}(0.25 \mu \mathrm{m})$, as well as increased the fraction of particles sized between $150 \mathrm{~nm}$ and $250 \mathrm{~nm}(0.15 \mu \mathrm{m}$ and 0.25 $\mu \mathrm{m})$. Therefore, the milled zinc borate should be capable of penetrating the nanocapillary network of the $1 \mu \mathrm{m}$ to $10 \mu \mathrm{m}$ thick lignified cell wall (Fujino and Itoh 1998), in which the membrane openings in a bordered pit are typically $400 \mathrm{~nm}$ to $600 \mathrm{~nm}$, and the window pit diameter is typically of $10,000 \mathrm{~nm}$. It should be noted that the milled sample of zinc borate does not include particles larger than $25,000 \mathrm{~nm}$, which would occlude some mesopores and clog tracheids, preventing the preservative from penetrating the wood (Freeman and McIntyre 2008). At the same time the product adherence to the cell wall caused increased leaching resistance, despite the improved distribution of particles and penetration into wood associated with particle diameters below 1000 nm (Zhang et al. 2012).

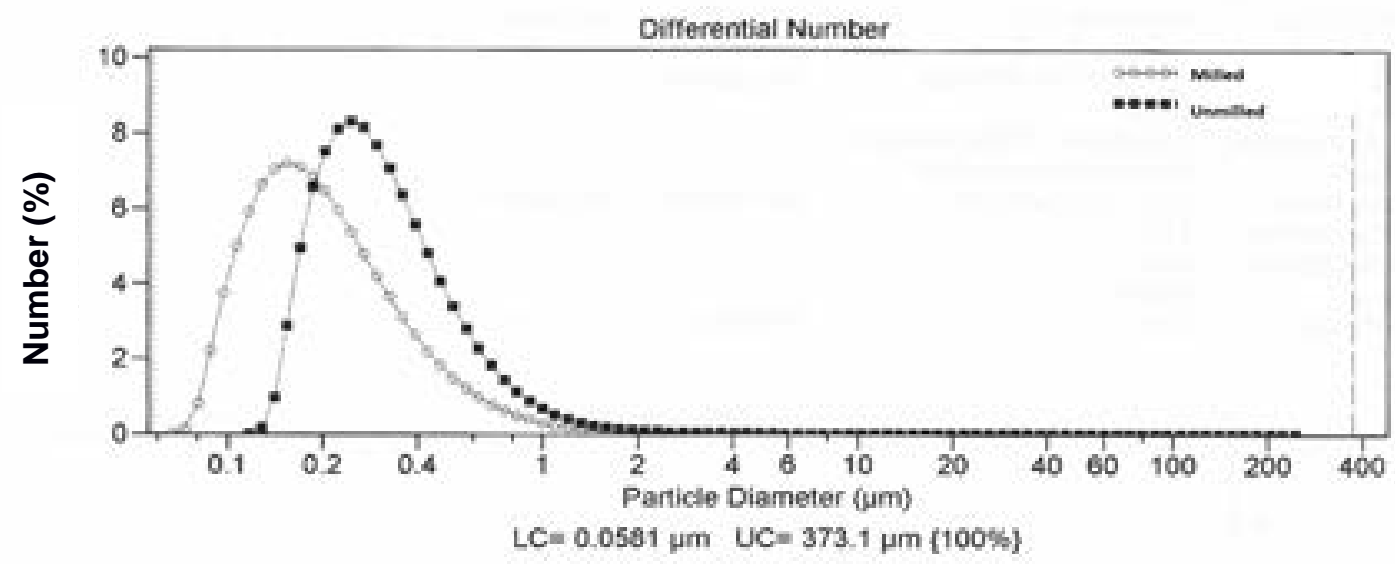

Fig. 2. Particle volume distribution of unmilled (black squares) and milled (white circles) zinc borate

The SEM images of zinc borate particles (Fig. 3) indicated no changes in the appearance of the solids (aside from particle size) once zinc borate was milled, despite the temperature rise during the milling process. At the same time, it also showed how unmilled solid particles tend to join together, which does occur to a lesser extent with the milled solid, perhaps due to the addition of milling dispersants.

a)

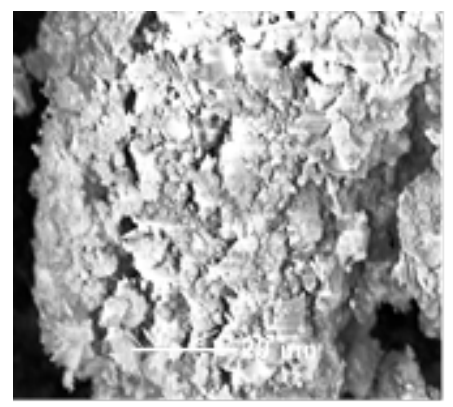

b)

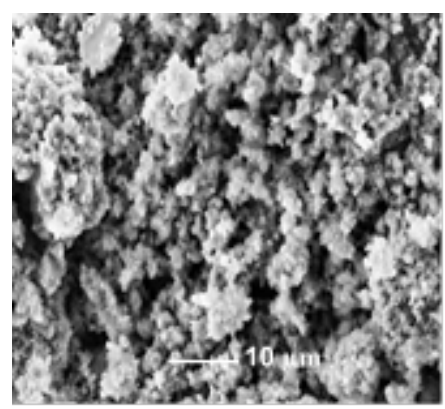

Fig. 3. SEM images of zinc borate particles: a) unmilled; and b) milled.

\section{Fungus Growth on Zinc Borate-supplemented Culture Medium}

Zinc borate suspensions were prepared to determine the fungicidal effectiveness (on culture medium and wood) for milled and unmilled products, respectively, at a $\mathrm{pH}$ of 
8.32 and 8.22, and an average decanting time of 28:19 $\mathrm{min}$ and $38: 11 \mathrm{~min}$. In order to maintain its homogeneity and low decanting time, the suspensions were kept in agitation mode.

The effect of milled and unmilled zinc borate samples on the initial growth rate of three white-rot and one brown-rot fungal species was studied. Figure 4 shows that the MIC value for the assayed fungus. The brown-rot fungus was the most sensitive -i.e., having the lowest initial growth rate - to milled zinc borate in the culture medium. For $P$. atropurpurascens and G. trabeum, the MIC values for milled and unmilled zinc borate samples was $1.25 \%(\mathrm{w} / \mathrm{w})$, and for T. versicolor and P. chrysosporium it was $2.5 \%(\mathrm{w} / \mathrm{w})$ -i.e., the highest concentration tested. The growth curves were analogous for milled and unmilled products, with no significant differences at a significance level of 0.05 . This result showed that the fungicide capacity of zinc borate was not affected by the particle size.

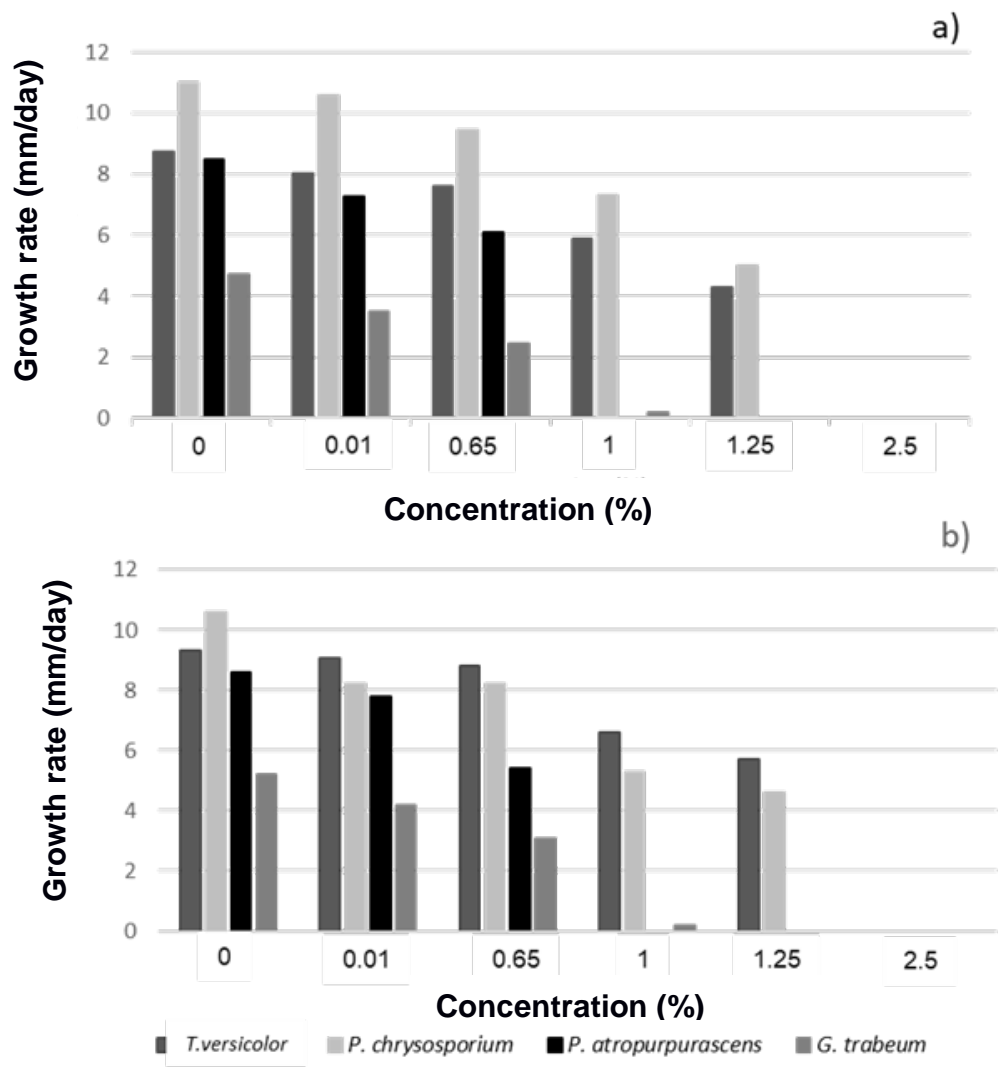

Fig. 4. Inhibitory effect of zinc borate on the initial growth rate of white- and brown-rot fungi; initial growth rate of test species on culture medium supplemented with $0,0.01 \%, 0.65 \%, 1.00 \%, 1.25 \%$, and $2.5 \%$ zinc borate: a) unmilled, b) milled

\section{Wood Protecting Action and Leaching of Milled and Unmilled Zinc Borate Samples Impregnated in Wood Substrates}

Table 1 shows the zinc borate retentions in wood and the mass losses of the wood specimens treated with both milled and unmilled zinc borate after being exposed to fungi. 
Table 1. Weight Loss of Wood Samples Treated with Milled and Unmilled Zinc Borate and Control Against Wood-decaying Fungi

\begin{tabular}{|c|c|c|c|c|c|c|c|}
\hline \multirow[b]{2}{*}{ P. taeda } & \multicolumn{3}{|c|}{ Milled Zinc Borate } & \multicolumn{3}{|c|}{ Unmilled Zinc Borate } & \multirow[t]{2}{*}{ Control } \\
\hline & & Unleached & Leached & & Unleached & Leached & \\
\hline & Retention & $\begin{array}{c}\text { Weight } \\
\text { loss }\end{array}$ & $\begin{array}{c}\text { Weight } \\
\text { loss }\end{array}$ & Retention & $\begin{array}{c}\text { Weight } \\
\text { loss }\end{array}$ & $\begin{array}{l}\text { Weight } \\
\text { loss }\end{array}$ & $\begin{array}{c}\text { Weight } \\
\text { loss }\end{array}$ \\
\hline & $\mathrm{kg} / \mathrm{m}^{3}$ & $\%(\mathrm{sd})$ & $\%(\mathrm{sd})$ & $\mathrm{kg} / \mathrm{m}^{3}$ & $\%(\mathrm{sd})$ & $\%(\mathrm{sd})$ & $\%(\mathrm{sd})$ \\
\hline $\begin{array}{c}T . \\
\text { versicolor }\end{array}$ & 17.6 & $0.1(0)$ & $3.1(0.7)$ & 7.7 & $1.3(0.5)$ & $5.2(1.2)$ & $29.6(5.2)$ \\
\hline & 30.2 & $3.2(1.1)$ & $0.8(0.3)$ & 23.8 & $3.5(0.7)$ & $4.8(1.4)$ & \\
\hline $\begin{array}{c}\text { G. } \\
\text { trabeum }\end{array}$ & 17.6 & $0.2(0.1)$ & $1.1(0.9)$ & 7.7 & $1.2(0.3)$ & $3.1(0.8)$ & $24.3(1.2)$ \\
\hline & 30.2 & $2(0.9)$ & $3.5(1.9)$ & 23.8 & $3.5(1.4)$ & $4.1(0.9)$ & \\
\hline E. grandis & & & & & & & \\
\hline & Retention & $\begin{array}{c}\text { Weight } \\
\text { loss }\end{array}$ & $\begin{array}{c}\text { Weight } \\
\text { loss }\end{array}$ & Retention & $\begin{array}{c}\text { Weight } \\
\text { loss }\end{array}$ & $\begin{array}{c}\text { Weight } \\
\text { loss }\end{array}$ & $\begin{array}{c}\text { Weight } \\
\text { loss }\end{array}$ \\
\hline & $\mathrm{kg} / \mathrm{m}^{3}$ & $\%(\mathrm{sd})$ & $\%(\mathrm{sd})$ & $\mathrm{kg} / \mathrm{m}^{3}$ & $\%(\mathrm{sd})$ & $\%(\mathrm{sd})$ & $\%(\mathrm{sd})$ \\
\hline $\begin{array}{c}T . \\
\text { versicolor }\end{array}$ & 12.1 & $0.2(0)$ & $2.2(1.2)$ & 4.4 & $3.7(1.1)$ & $5.9(0.5)$ & $29.6(3.3)$ \\
\hline & 22.3 & $4.3(0.8)$ & $3.1(1.8)$ & 7.6 & $3.9(0.5)$ & $6.1(0.9)$ & \\
\hline $\begin{array}{c}\text { G. } \\
\text { trabeum }\end{array}$ & 12.1 & $0(0)$ & $3.5(1.4)$ & 4.4 & $2.8(0.9)$ & $4.2(0.9)$ & $19.9(3.2)$ \\
\hline & 22.3 & $0(0.3)$ & $3.1(0.4)$ & 7.6 & $2.1(1.1)$ & $3.9(0.8)$ & \\
\hline $\begin{array}{c}\text { Populus } \\
\text { sp. }\end{array}$ & & & & & & & \\
\hline & Retention & $\begin{array}{l}\text { Weight } \\
\text { loss }\end{array}$ & $\begin{array}{c}\text { Weight } \\
\text { loss }\end{array}$ & Retention & $\begin{array}{c}\text { Weight } \\
\text { loss }\end{array}$ & $\begin{array}{c}\text { Weight } \\
\text { loss }\end{array}$ & $\begin{array}{c}\text { Weight } \\
\text { loss }\end{array}$ \\
\hline & $\mathrm{kg} / \mathrm{m}^{3}$ & $\%(\mathrm{sd})$ & $\%(\mathrm{sd})$ & $\mathrm{kg} / \mathrm{m}^{3}$ & $\%(\mathrm{sd})$ & $\%(\mathrm{sd})$ & $\%(\mathrm{sd})$ \\
\hline $\begin{array}{c}T . \\
\text { versicolor }\end{array}$ & 13.2 & $0(0.1)$ & $2.1(1.4)$ & 5.2 & $2.5(0,6)$ & $4.5(1.4)$ & $26.4(4.1)$ \\
\hline & 28.2 & $0(0)$ & $9.7(3.1)$ & 8.6 & $3.1(1.4)$ & $5.6(1.4)$ & \\
\hline $\begin{array}{c}\text { G. } \\
\text { trabeum }\end{array}$ & 13.2 & $0.5(0.2)$ & $0.2(0.1)$ & 5.2 & $2.2(0.7)$ & $7.4(0.9)$ & $19.6(3.5)$ \\
\hline & 28.2 & $0(0)$ & $0.6(0.1)$ & 8.6 & $1.3(1.2)$ & $6.6(0.9)$ & \\
\hline
\end{tabular}

"sd" denotes standard deviation.

Retention results for milled and unmilled zinc borate samples after vacuum treatment differed significantly according to wood species. As shown in Table 1, pine had a higher retention than eucalypt and poplar wood species. Varied retentions can be attributed to different pore-size distributions of the ultrastructure of various species studied, as similar behavior was reported for wood impregnated with nano-zinc (Németh et al. 2013). Retention values for pine wood were slightly lower than those reported by Lykidis et al. (2013) $\left(17.9 \mathrm{~kg} / \mathrm{m}^{3}\right)$ in a study using a vacuum-pressure-vacuum method with $3 \%$ w/w suspension and was larger than those obtained by Mantanis et al. (2014) $\left(5.64 \mathrm{~kg} / \mathrm{m}^{3}\right)$ using a vacuum-vacuum method with $2.5 \% \mathrm{w} / \mathrm{w}$ suspension. Both research groups worked with Pinus nigra L. wood. Those variations can be attributed to the concentration of the dispersions used and the different impregnating methods or differences between wood anatomy characteristics of pine species. However, when comparing the retention values in 
Table 1 with those reached with a micronized product (such as micronized copper azole (MCA) in rubberwood), the same retention increase was observed when the suspension concentration were increased. This was contrary to an earlier finding that retention values were lower (2.8 to $11.5 \mathrm{~kg} / \mathrm{m}^{3}$ ) Shukla et al. (2019).

Weight loss of untreated specimens consistently amounted to nearly or over $20 \%$, except for G. trabeum colonizing Populus sp., thus validating the test conditions according to the EN113 (1996) standard. Mass loss of treated wood samples without fungus was reduced by less than $1 \%$ in all cases.

Table 1 shows that both milled and unmilled zinc borate protected the wood without leaching, as the wood is considered protected when the mass losses obtained is of less than 3\%, according to EN 113 (1996). The exception was for E. grandis against T. versicolor, which presented a mass loss close to $4 \%$ at the higher value of zinc borate retention tested but still is considered protected.

Populus wood was protected by zinc borate against fungal action except against $T$. versicolor, with only negligible weight losses found for leached samples.

In all cases the mass losses of the samples treated with micronized zinc borate were lower compared to those treated with unmilled solid, which was attributed to a better distribution of the solid inside the wood because of the higher percentage of smaller sized particles. The micronized zinc borate at the lowest value of retention tested consistently led to smaller weight losses than it did at the highest retention value. No significant differences $(\alpha=0.05)$ were found between leached and non-leached samples of pine treated with milled zinc borate at the retention values tested. Protection against $T$. versicolor was consistent with the findings of Mantanis et al. (2014). However, in contrast with what these authors reported for Tyromyces palustris, the milled zinc borate used in this study showed fungicidal activity against $G$. trabeum.

Finally, it can be observed that the mass losses showed the same tendency reported by Clausen et al. (2011) and by Lykidis et al (2016a): there occurred greater leaching at a higher concentration of the suspension.

Prior to the study on $\mathrm{Zn}$ and $\mathrm{B}$ loss by leaching, different wood digestion conditions were assayed, in which different acidic mixtures were used: $\mathrm{HNO}_{3}, \mathrm{HNO}_{3}-\mathrm{HCl}$, and $\mathrm{HNO}_{3}-$ $\mathrm{HCl}-\mathrm{H}_{2} \mathrm{O}_{2}$. In each case, retrieved $\mathrm{Zn}$ concentrations were evaluated. For the three conditions tested, the highest $\mathrm{Zn}$ recovery was obtained for E. grandis. The best results were obtained with $\mathrm{HNO}_{3}$ for eucalyptus, and $\mathrm{HNO}_{3}-\mathrm{HCl}$ of 50:50 ratio for pine.

Table 2. Zn (mg/L) Recovered from Wood Digestion Using Various Acidic Mixtures: $\mathrm{HNO}_{3}, \mathrm{HNO}_{3}-\mathrm{HCl}$, and $\mathrm{HNO}_{3}-\mathrm{HCl}_{-} \mathrm{H}_{2} \mathrm{O}_{2}$, for $E$. grandis and $P$. taeda

\begin{tabular}{|c|c|c|}
\hline & Acidic Mixtures & Zn (mg/L) \\
\hline E. grandis & $\mathrm{HNO}_{3}$ & 17 \\
\hline & $\mathrm{HNO}_{3}-\mathrm{HCl}$ & 15 \\
\hline & $\mathrm{HNO}_{3}-\mathrm{HCl}-\mathrm{H}_{2} \mathrm{O}_{2}$ & 7 \\
\hline P. taeda & $\mathrm{HNO}_{3}$ & 6.7 \\
\hline & $\mathrm{HNO}_{3}-\mathrm{HCl}$ & 12 \\
\hline & $\mathrm{HNO}_{3}-\mathrm{HCl}-\mathrm{H}_{2} \mathrm{O}_{2}$ & 7.4 \\
\hline
\end{tabular}

Table 3 shows the percentages of leached $\mathrm{Zn}$ and $\mathrm{B}$, determined as the difference between initial quantities of $\mathrm{Zn}$ and $\mathrm{B}$ with those obtained after leaching according to EN 
84 (1997). Both data were obtained from the acid digestion of the treated wood. These tests were done only for P. taeda and one of the hardwood species, E. grandis.

Table 3. Percentage of $\mathrm{Zn}$ and B Lost Through Leaching of Milled and Unmilled Zinc Borate

\begin{tabular}{|c|c|c|c|c|}
\hline & & \multicolumn{3}{|c|}{ P. taeda } \\
\hline & & $\left(\mathbf{k g} / \mathbf{m}^{3}\right)$ initial & $\left(\mathbf{k g} / \mathbf{m}^{3}\right)$ leached & $\begin{array}{c}\%\left(\mathbf{k g} / \mathbf{m}^{3}\right) \\
\text { lost }\end{array}$ \\
\hline Unmilled & Zn & 1.94 & 1.01 & 52.1 \\
\hline & B & 4.91 & 2.11 & 62.9 \\
\hline Milled & Zn & 2.66 & 0.92 & 34.6 \\
\hline & B & 2.91 & 2.15 & 73.9 \\
\hline & & \multicolumn{3}{|c|}{ E. grandis } \\
\hline & & $\left(\mathbf{k g} / \mathbf{m}^{3}\right)$ initial & $\left(\mathbf{k g} / \mathbf{m}^{3}\right)$ leached & $\begin{array}{c}\text { \% }\left(\mathbf{k g} / \mathbf{m}^{3}\right) \\
\text { lost }\end{array}$ \\
\hline Unmilled & Zn & 2.26 & 1.85 & 81.8 \\
\hline & B & 4.73 & 4.44 & 93.9 \\
\hline Milled & Zn & 1.08 & 0.66 & 61.1 \\
\hline & B & 4.27 & 3.11 & 72.8 \\
\hline
\end{tabular}

The wood treated with unmilled sample was more susceptible to leaching, leaving the wood unprotected for all the retentions tested and in all three-wood species studied (Tables 1 and 3).

The milled zinc borate used in this study does not leach easily compared with ammoniacal zinc borate (Ibáñez et al. 2014). The weight loss due to leaching was significant only for the hardwood species $(\alpha=0.05)$. This was in line with the insignificant leaching reported for pine wood impregnated with nanometric $\mathrm{ZnO}$ (70 $\mathrm{nm}$ particle size) (Clausen et al. 2011).

In Fig. 5, E. grandis SEM images are shown. Unmilled zinc borate was hardly distributed throughout the wood, instead accumulated as disperse and scarce crystals (arrow in Fig. 5b). On the other hand, wood treated with milled zinc borate showed white deposits on the internal walls within the wood tissue and accumulated in the cellular wall (arrow in Fig. 5c). However, after leaching the milled product accumulated in aggregates (smaller-sized particles joined together forming larger-sized particles), in the cellular lumen due to the presence of moisture (arrow in Fig. 5d) therefore preventing them from leaching out of the wood matrix. The same thing happened with copper compounds (Matsunaga et al. 2007, 2009; Leach and Zhang 2010); it is reported that leaching from MCQ copper (Alkaline Micronized Copper Quaternary) -treated wood amounts to half the amount leached from wood treated with ACQ (Alkaline Copper Quaternary) (McIntyre and Freeman 2009).

Zinc borate was observed to behave differently in pine wood. Milled zinc borate was detected as large white clusters both in the cellar walls and in the lumens (as indicated with an arrow in Fig. 6b). However, after leaching, the cellar lumens were left empty. For the micronized and particulate copper present in MCA (micronized copper azole) and ACQ 
in southern pine, Feng et al. (2019) identify the parenchyma cells associated with the radial and axial resin channel network as major copper deposition sites, with different distribution in the wood.

a)

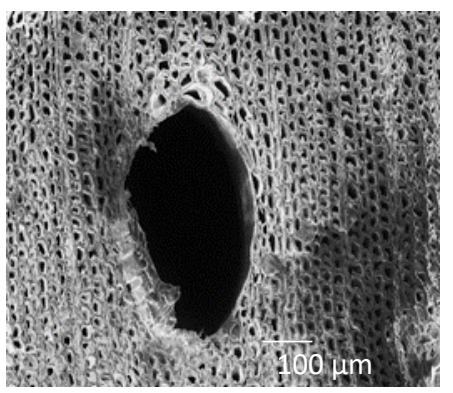

c)

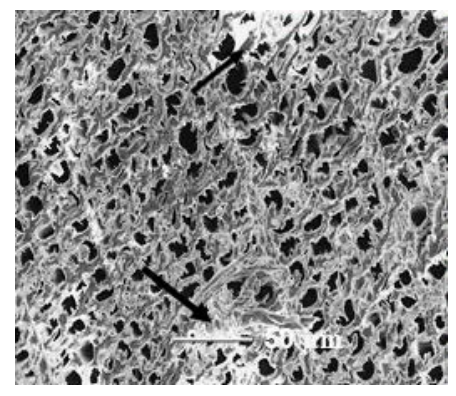

b)

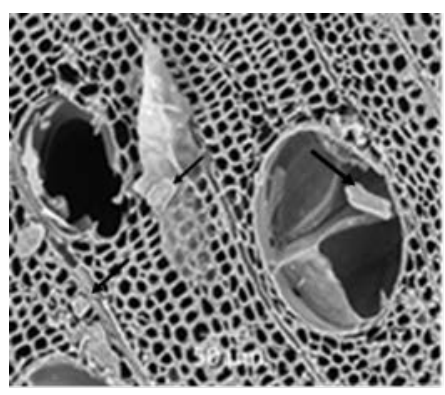

d)

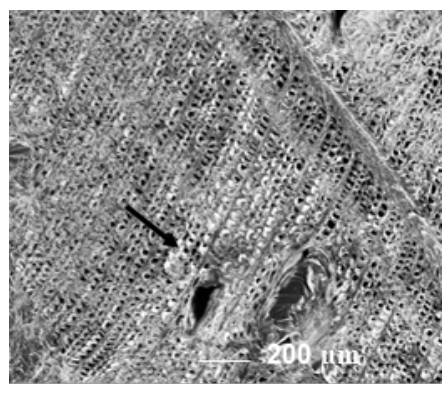

Fig. 5. SEM images of Eucalyptus grandis: a) untreated, b) with unmilled ZnB, c) with milled ZnB, d) leached wood, previously treated with milled ZnB

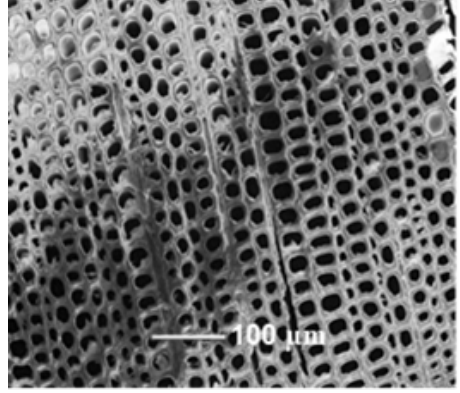

a)

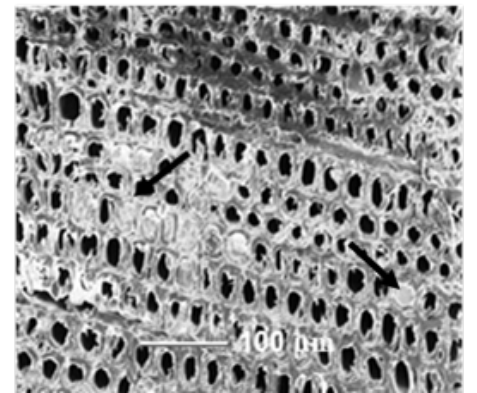

b)

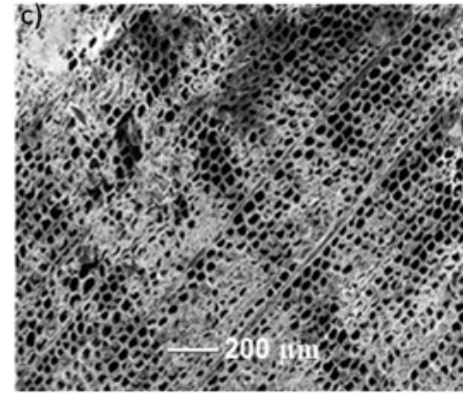

c)

Fig. 6. SEM images of Pinus taeda: a) untreated, b) with milled $\mathrm{ZnB}$, and c) b extended

The SEM images show that both milled and unmilled zinc borate were not distributed homogeneously section-wise; nor was it found to form aggregates or deposits in a consistent pattern that could have led to the identification of preferential deposition zones, such as the middle lamella or the secondary wall. In some sections, no deposits were found. In the following studies, the apparent greater presence of milled zinc borate within the wood (when compared to the one treated with the unmilled product) will be verified by energy-dispersive analysis of X-rays (EDX).

The results can be considered as promising, since it will be verified that a reduction in the particle size leads to an improvement in wood protection, despite the $\mathrm{Zn}$ and B elemental loss percentage being similar to those presented by wood treated with the 
unmilled product. The improvement when using the milled product can be attributed partly to a more homogeneous distribution within the porous microstructure of the wood (Matsunaga et al. 2008), which at the same time depends on particle size and increased penetration of those micronized particles with diameters smaller than the bordered pits (Shukla et al. 2019). However, this neither improves nor decreases the fungicidal properties of the product.

This study thus revealed that the enhancement in wood protection can be achieved at a very low cost, because the impregnating material was synthetized from commodities by application of a low energetic cost process. This is in contrast, for instance, to the synthesis of nano- or micro-sized materials that require expensive catalysts. Further studies are required to provide a more comprehensive knowledge on how to reduce leaching even more by incorporating additives in the formulation.

\section{CONCLUSIONS}

1. In this work, zinc borate was milled and compared with the unmilled material, against wood rotting fungi. Both solids are able to protect the wood when they are not subjected to leaching.

2. The milled zinc borate material tested, although did not improve the fungicidal action against brown- and white-rot fungi, did prevent leaching, which would allow its application in environments of high moisture content.

\section{ACKNOWLEDGMENTS}

The authors are grateful for Perrin S. A., Uruguay for providing zinc borate used in this study. They are grateful to Dr. Prof. Heber Abreu, Federal Rural University of Rio de Janeiro, Brazil, for instructions in SEM technology, Jorge Adum of INCA Paintings Ltd., Uruguay, and Tania Rabinovich for text translation.

\section{REFERENCES CITED}

Akhtari, M., and Nicholas, D. (2013). "Evaluation of particulate zinc and copper as wood preservatives for termite control,” Eur. J. Wood Prod. 71(3), 395-396. DOI: 10.1007/s00107-013-0690-7

Anzano, J., and González, P. (2000). "Determination of iron and copper in peanuts by flame atomic absorption spectrometry using acid digestion," Microchem J. 64(2), 141-145. DOI: 10.1016/S0026-265X(99)00021-1

AWPA A7-12 (2014). "Standard wet ashing procedures for preparing wood for chemical analysis,” American Wood Protection Association, Birmingham, Alabama, USA.

Borokhov, O., and Rothenburger, S. (2000). "Rapid dye decolourization method for screening potential wood preservatives,” App. Env. Microbial. 66(12), 5457-5459. DOI: 10.1128/AEM.66.12.5457-5459.2000 
Civardi, C., Schwarze, F., and Wick, P. (2015a). "Micronized copper wood preservative: An efficiency and potential health risk assessment for copper-based nanoparticles," Environ. Pollut. 2000, 126-132. DOI: 10.1016/j.envpol.2015.02.018

Civardi, C., Schubert, M., Fey, A., Wick, P., and Schwarze F. (2015b). "Micronized copper wood preservatives: Efficacy of ion, nano, and bulk copper against the brown rot fungus Rhodonia placenta,” PLoS ONE 10(11), e0142578. DOI: 10.1016/j.envpol.2015.02.018

Clausen, C., Yang, V. W., Arango, R. A., and Green III, F. (2009). “Feasibility of nanozinc oxide as a wood preservative," in: Proceedings of One Hundred Fifth Annual Meeting of the American Wood Protection Association, Stockholm, Sweden.

Clausen, C., Green III, F., and Kartal, N. (2010). "Weatherability and leach resistance of wood impregnated with nano-zinc oxide,” Nanoscale Res. Lett. 5(9), 1464-1467. DOI: 10.1007/s11671-010-9662-6

Clausen, C., Kartal, N., Arango, R., and Green III, F. (2011). “The role of particle size of particulate nano-zinc oxide wood preservatives on termite mortality and leach resistance,” Nanoscale Res. Lett. 6, 427- 431. DOI: 10.1186/1556-276X-6-427

Dawson, B. S., Parker, F. G. F., Cowan, J., Croucher, M. C., Hong, S., and Cummins, N. (1990). "Interlaboratory determination of boron compounds in preservative treated timber,” Anal. Chim. Acta 236, 423-430. DOI: 10.1016/S0003-2670(00)83343-7

Eaton, R. A., and Hale, M. D. C. (1993). Wood. Decay, Pests and Protection, Chapman and Hall, London.

EN 113 (1996). "Wood preservatives - Method for determining the protective effectiveness against wood destroying Basidiomycetes,” European Committee for Standardization, Brussels.

EN 84 (1997). "Wood preservatives - Accelerated ageing of treated wood prior to biological testing,” European Committee for Standardization, Brussels.

European Commission (2011). "European Commission Recommendation of 18 October 2011 on the definition of nanomaterial (Text with EEA relevance) (2011/696/EU)," Official Journal of the European Union.

Feng, D., Turner, M., Limaye, A., Knackstedt, M., and Evans, P. (2019). “Accumulation of copper in parenchyma cells in southern pine wood treated with micronized and amine-copper preservatives,” (IRG/WP 19-20657), International Research Group on Wood Preservation, Stockholm, Sweden.

Fujino, T., and Itoh, T. (1998). "Changes in the three-dimensional architecture of the cell wall during lignification of xylem cells in Eucalyptus tereticornis," Holzforschung 52(2), 111-116. DOI: 10.1515/hfsg.1998.52.2.111

Freeman, M., and McIntyre, C. (2008). “A comprehensive review of copper-based wood preservatives, with a focus on new micronized or dispersed copper systems," Forest Prod. J. 58(11), 6-27.

Ghorbani-Kookandeh, M., Taghiyari, H., and Siahposht, H. (2014). "Effects of heat treatment and impregnation with zinc-oxide nanoparticles on physical, mechanical, and biological properties of beech wood,” Wood Sci. Technol. 48(4), 727-736. DOI: 10.1007/s00226-014-0627-2

Harrison, W. T. A., Gier, T. E., and Stucky, G. D. (1993). "The synthesis and Ab initio structure determination of $\mathrm{Zn}_{4} \mathrm{O}\left(\mathrm{BO}_{3}\right)_{2}$, a microporous, zinc borate constructed of "fused" subunits, of three- and five-membered rings," Angew. Chem. Int. Ed. 32(5), 724- 726. DOI: 10.1002/anie.199307241 
Hatvani, N., and Mécs, I. (2003). "Effects of certain metals on the growth, dye decolourisation, and enzyme activity of Lentinula edodes,” Ecotox. Environ. Safe. 55(2), 199-203. DOI: 10.1016/S0147-6513(02)00133-1

Hu, Z., and Qi, L. (2014). "Reference module in earth systems and environmental sciences,” in: Treatise on Geochemistry ( $2^{\text {nd }}$ Ed.), pp. 87-109.

Ibáñez, C. M., Mantero, C., Ibarra, A., and Rabinovich, M. (2014). Ammoniacal Zinc Borate as Solid Wood Preservative (IRG/WP 14-30659), International Research Group on Wood Preservation, Stockholm, Sweden.

Jun Zhang, W., Zhang, R., and Leach, M. (2012). "Micronized wood preservative formulations comprising boron compounds,” United States Patent 8,168,304 B2.

Kartal, N., Green III, F., and Clausen, C. (2009). "Do the unique properties of nanomaterials affect leachability or efficacy against fungi and termites?” Int. Biodeterior. Biodegrad. 63(4), 490-495. DOI:10.1016/j.ibiod.2009.01.007

Kurz, D., Roach, J., and Eyring, E. J. (1973). "Determination of zinc by flameless atomic absorption spectrophotometry,” Anal. Biochem. 53(2), 586-593. DOI: 10.1016/00032697(73)90110-3

Leach, R., and Zhang, J. (2010). “Micronized wood preservative formulations,” United States Patent 7,674, 81 B2.

Lykidis, C., Mantanis, G., Adamopoulos, S., Kalafata, K., and Arabatzis, I. (2013). "Effects of nano-sized zinc oxide and zinc borate impregnation on Brown rot resistance of black pine (Pinus nigra L.) wood,” Wood Mater. Sci. Eng. 8(4), 242244. DOI: 10.1080/17480272.2013.834969

Lykidis, C., de Troya, M., Conde, M., Galván, J., and Mantanis, G. (2016a). The Termite Resistance of Wood Impregnated with Nano-zinc Oxide and Nano-zinc Borate Dispersions (IRG/WP 16-30691), International Research Group on Wood Preservation, Stockholm, Sweden.

Lykidis, C., Bak, M., Mantanis, G., and Németh, R. (2016b). “Biological resistance of pine wood treated with nano-sized zinc oxide and zinc borate against brown-rot fungi,” Eur. J. Wood 74(6), 909-911. DOI: 10.1007/s00107-016-1093-3

Lykidis, C., de Troya, M., Conde, M., Galván, J., and Mantanis, G. (2018). “Termite resistance of beech wood treated with zinc oxide and zinc borate nanocompounds," Wood Mater. Sci. Eng. 13(1), 45-49. DOI: 10.1080/17480272.2016.1257651

McIntyre, C., and Freeman, M. (2009). "Micronized copper," Annual Meeting of the American Wood Protection Association, Birminghan, Alabama, USA.

Mantanis, G., Terzi, E., Kartal, N., and Papadopoulos, A. (2014). "Evaluation of mold, decay and termite resistance of pine wood treated with zinc- and cooper-based nanocompounds,” Int. Biodeterior. Biodegrad. 90, 140-144. DOI: 10.1016/j.ibiod.2014.02.010

Matsunaga, H., Kiguchi, M., and Evans, P. (2007). Microdistribution of Metals in Wood Treated with Nano-copper Wood Preservative (IRG/WP 07-40460), International Research Group on Wood Preservation, Stockholm, Sweden.

Matsunaga, H., Kiguchi, M., Roth, B., Evans, P.D. (2008). "Visualisation of metals in pine treated with preservative containing copper and iron nanoparticles," IAWA Journal 29(4), 387-396. DOI: 10.1163/22941932-90000193.

Matsunaga, H., Kiguchi, M., and Evans, P. (2009). "Microdistribution of coppercarbonate and iron oxide nanoparticles in treated wood," J Nanopart Resh 11(5), 1087-1098. DOI: 10.1007/s11051-008-9512-y 
Németh, R., Bak, M., Mbouyem Yimmou, B., Csupor, K., Molna'r, S., and Csóka, L. (2013). "Nano-zinc as an agent against wood destroying fungi," in: Proc. of the Annual IAWS Meeting, $5^{\text {th }}$ International Symposium on the Interaction of Wood with Various Forms of Energy, J. Kúdela and M. Babiak (eds.), International Academy of Wood Science, Technical University, Zvolen, Slovakia, pp. 59-63.

Ramanathan, T., and Ting, Y. J. (2015). "Selection of wet digestion method for metal quantification in hazardous solid wasted,” J. Environ. Chem. Eng. 3(3), 1459-1467. DOI: 10.1016/j.jece.2015.05.006.

Shah, V., Dobiásová, P., Baldrian, P., Nerud, F., Kumar, A., and Seal, S. (2010). "Influence of iron and copper nanoparticle powder on the production of lignocellulose degrading enzymes in the fungus Trametes versicolor," J. Hazard. Mat. 178(1-3), 1141-1145. DOI: 10.1016/j.jhazmat.2010.01.141

Shukla, S., Zhang, J., and Kamdem, D. (2019). "Pressure treatment of rubberwood (Heavea brasiliensis) with waterborne micronized copper azole: Effects on retention, copper leaching, decay resistance and mechanical properties," Construction and Building Materials 216, 576-587. DOI: 10.1016/j.conbuildmat.2019.05.013.

Stirling, R., and Temiz, A. (2014). "Fungicides and insecticides used in wood preservation,” in: Deterioration and Protection of Sustainable Biomaterials , T. P. Schultz, B. Goodell, and B. Nicholas (eds.), American Chemical Society, Washington, DC, pp. 185-201.

Tascioglu, C., Yoshimura, T., and Tsunoda, K. (2013). "Biological performance of wood-plastic composites containing zinc borate: Laboratory and 3-year field test results,” Composites: Part B 51(), 185-190. DOI: 10.1016/j.compositesb.2013.03.034

Tascioglu, C., Umemura, K., Yoshimura, T., and Tsunoda, K. (2014). "Biological performance of zinc borate-incorporated particleboard: Effects of leaching on efficacy,” Composites: Part B Eng. 57, 31-34.

DOI: 10.1016/j.compositesb.2013.09.037

Tascioglu, C., Umemura, K., and Yoshimura, T. (2017). “Seventh-year durability evaluation of zinc borate incorporated wood-plastic composites and particleboard," Composites Part B Eng. 137, 123-128. DOI: 10.1016/j.compositesb.2017.11.011.

Wilson, W. J. (1958). “The determination of boron in treated wood,” Anal. Chim. Acta 19(), 516-519. DOI: 10.1016/S0003-2670(00)88210-0

Xue, W., Kennepohl, P., and Ruddick, J. (2014). Chemistry of Copper Preservative Treated Wood (IRG/WP 14-30651), International Research Group on Wood Preservation, St George, Utah, USA.

Article submitted: March 18, 2019; Peer review completed: May 25, 2019; Revised version received: June 4, 2019; Accepted: June 5, 2019; Published: June 19, 2019.

DOI: 10.15376/biores.14.3.6231-6246 